\title{
Investigation of the Biomass and Nutrient Content of Green Manuring Plants as Second Crops in Hungary
}

\author{
Péter MIKÓ, Gergő KOVÁCS*, István BALLA, László VASA, Csaba GYURICZA \\ Szent István University, Institute of Crop Production, 1 Páter Károly 2100, Gödöllö, \\ Hungary; kovacs.gergopeter@mkk.szie.hu ( ${ }^{*}$ correspondingauthor)
}

\begin{abstract}
The growth, and the development and trends of the nutrient content parameters of three different plant species (Phacelia tanacecifolia, Sinapis alba, Raphanus sativus) grown as secondary crops for green manure, as a function of two different fertiliser doses $(0 \mathrm{~kg} / \mathrm{ha} \mathrm{N} ; 50$ $\mathrm{kg} / \mathrm{ha} \mathrm{N}$ ), was studied under unfavourable site conditions at the Crop Production and Biomass Utilisation Demonstration Centre of the Szent István University, Gödöllö, Hungary. The application of the small, $50 \mathrm{~kg} / \mathrm{ha}$ dose of nitrogen increased the biomass yield in each case, to 2.78-3.11 times that of the control field. The dry matter content of the produce increased only by 2.11-2.66 times, as the water content of the green manure plants also increased as a result of the nitrogen supplement. The increased amount of nitrogen boosted the availability of all of the other macro elements for the plants. In view of the present findings it can be recommend the application of some nitrogen fertiliser in the given site before growing some crop for use as green manure in all cases but where the straw after cereals is left on the soil surface nitrogen should be applied to alleviate the pentosan effect and to increase the uptake of macro elements.
\end{abstract}

Keywords: biomass, green manuring, mustard, oil radish, phacelia

Abbreviations: Phacelia tanacecifolia (I.), Sinapis alba (II.), Raphanus sativus (III.), no fertilization (NF), with fertilization (WF), change in nutrient content $(\mathrm{CNC})$

\section{Introduction}

Climate and soil conditions have a profound impact on the goals of the production of green manure crops/ catch crops. In West European countries with higher annual precipitation the key objective is to prevent the leaching of nutrients, while in the no-tillage systems applied in the USA the primary aim is to improve the structure of the soil. In Hungary however, besides the protection of the soil structure, increasing the soil's nutrient content is also a crucial objective as soils in this country have been inadequately supplied with nutrient for quite a number of years.

Problems in addition to the shortage of farmyard manure resulting from the decrease in livestock and the decline in fertiliser application are caused by the fact, that some of the biomass power plants that are being constructed are planned to be fuelled with wheat straw and maize stalks further reducing thereby the amount of organic materials and nutrients left on the fields after harvest (Birkás, 2010).

Catch crops play an important role in crop rotation in many countries, particularly in West Europe and in North America (Hall and Hartwig, 1989; Henderson, 1989; Larson et al., 1998; Rasmusen and Andersen, 1994). Crops take up the nutrients (primarily nitrogen) leached out of the soil and retain them for the next crop (Allison et al., 1998a, 1998b; Breland, 1995; Thorup-Kristensen et al., 2003). Moreover, they improve the soil's condition, alleviate soil compaction along with damage caused by erosion or deflation (Muller et al., 1989; Smith et al., 1987; Unger and Vigil, 1998). They contribute to the forming of soil aggregates, improve the soil's water intake and water retaining capacity and enhance the soil's stability (Andraski and Bundy, 2005; Burket et al., 1997; Stivers-Young, 1998).

Other benefits afforded by catch crops include the significant nematode controlling effects of the catch crop species belonging to the Brassicaceae and Hydrophyllacea families. Their nematode controlling effects will be observed whether they are produced as main crops or as green manure crops (Johnson et al., 1967; Lewis and Papavizas, 1971; Mojtahedi et al., 1991, 1993). By combining a suitable crop rotation scheme with the application of green manure, the number of nematodes can be significantly reduced, even to levels below the threshold over which they can cause economic damage (Chikaoka et al., 1982; Dickson and Hewlett, 1989; Duddington and Duthoit, 1960; Duddington et al., 1961; Kahnt, 1983). Inderjit (2004) demonstrated that growing Phacelia tanacecifolia, Sinapis alba or Raphanus sativus for green manure is an effective solution against the most dangerous pest of sugar beets, that is Heterodera schachtii. Moreover, green manure plants also provide a good habitat for useful organizations (Axelsen and Kristensen, 2000). 
48

By studying different schemes of manure/fertiliser application Bolton et al. (1985) found that the application of green manure increased the counts of bacteria utilizing the soil's organic and inorganic nitrogen content by 2-3 times, while boosting the effectiveness of a number of enzymes as well.

Another advantage of green manure plants is that the species producing large amounts of biomass, such as Phacelia tanacecifolia, are also good for use as fodder (Djordjevic, 2005). In analyzing the effects of green manure plants on the next crop Kahnt (1983) identified as many as 14 factors. Due to the large number of relevant factors the effectiveness of the application of green manure can be assessed only on the basis of accurate knowledge of the parameters of the site concerned.

The most important characteristics of a good green manure plant species include rapid growth, large biomass production and cheap sowing seeds. The objective of the research was to study three green manure plants featuring each of the above attributes, under unfavourable site conditions. Answers were sought also to the question of whether successful green manure application is possible without supplementary nitrogen application in view of the likely pentosan effect or nitrogen supplementation is indispensable. Another aspect of the study was the extent to which the delivered nitrogen increases the specific green mass and the specific dry mass output as well as the NPK uptake per hectare.

\section{Materials and methods}

The experiments were set up at the Crop Production and Biomass Utilisation Demonstration Centre of the Szent István University, Gödöllö, Hungary (NL 47³4'43"; EL 19'22'39"; $229 \mathrm{~m}$ above sea level). The site is on a slight east-west slope in a hilly area of heterogeneous features,

Tab. 1. Monthly amount of precipitation (P) and monthly average air temperature ( $\mathrm{t}$ ) from August to October (Gödöllo”, 2007-2009)

\begin{tabular}{ccccccc}
\hline \multirow{2}{*}{ Month } & \multicolumn{2}{c}{2007} & \multicolumn{2}{c}{2008} & \multicolumn{2}{c}{2009} \\
\cline { 2 - 7 } & $\begin{array}{c}\mathrm{P} \\
(\mathrm{mm})\end{array}$ & $\begin{array}{c}\mathrm{t} \\
\left({ }^{\circ} \mathrm{C}\right)\end{array}$ & $\begin{array}{c}\mathrm{P} \\
(\mathrm{mm})\end{array}$ & $\begin{array}{c}\mathrm{t} \\
\left({ }^{\circ} \mathrm{C}\right)\end{array}$ & $\begin{array}{c}\mathrm{P} \\
(\mathrm{mm})\end{array}$ & $\begin{array}{c}\mathrm{t} \\
\left({ }^{\circ} \mathrm{C}\right)\end{array}$ \\
\hline VIII. & 54.0 & 22.9 & 28.6 & 21.9 & 21.6 & 22.8 \\
IX. & 54.6 & 14.1 & 82.0 & 15.5 & 27.4 & 19.0 \\
X. & 55.2 & 10.5 & 20.2 & 11.8 & 50.2 & 10.6 \\
Total & 163.8 & - & 130.8 & - & 99.2 & - \\
\hline
\end{tabular}

characterised by different degrees of erosion and sedimentation in different places. The annual mean temperature is $9.4^{\circ} \mathrm{C}$ and the annual precipitation is $590 \mathrm{~mm}$. The average precipitation in the crucial period for secondary crops, from August to October, is $150 \mathrm{~mm}$ (Tab. 1).

From the aspect of the secondary crop, in terms of the precipitation during the growing season (between August and October), 2007 was a rainy year, 2008 was a year of average precipitation while 2009 was a dry year $(163.8 \mathrm{~mm}$, $130.8 \mathrm{~mm}$ and $99.2 \mathrm{~mm}$, respectively).

The site is located in the micro-region of low hills called "Gödöllöi-dombság”. The soil of the experimental plots is, according to the WRB soil classification; luvic calcic phaeozem. As a consequence of the degradation processes a variant of a shallow fertile layer and low humus content has developed in the site. The area is exposed to erosion and the soil is sensitive to compaction.

The key parameters of the experimental site are summed up in (Tab. 2). The soil is low in nitrogen, with excellent $\mathrm{P}_{2} \mathrm{O}_{5}$ supply and a good $\mathrm{K}_{2} \mathrm{O}$ supply.

The experiments with green manure plants grown as secondary crops were carried out between 2007 and 2009. The previous crop was winter wheat in every case, and the harvest was immediately followed by stubble stripping. The seeds of the secondary crop were sown in each year right after stubble treatment, on 15 August. Three different plant species (phacelia-Phacelia tanacecifolia Benth., white mustard-Sinapis alba L. and oil radish-Raphanus sativus L. convar. oleiferus (Mill.) Metzger) were grown, two different fertiliser doses were applied and the experiment was designed in three replications, in strips. Ammonium nitrate fertiliser was applied, incorporated in the course of stubble treatment. The seeds of the green manure plants were sown in accordance with the sowing seed norms prescribed in technical literature (Antal, 2000) (Tab. 3).

The biomass measurements and the sampling required for the green manure nutrient content tests were carried out in early November. The NPK content was measured in 1 gram of ground absolute dry sample by means of digestion by undiluted sulphuric acid and by way of decomposition by heat in a $30 \%$ hydrogen-peroxide solution. After decomposition the $\mathrm{N}, \mathrm{P}$ and $\mathrm{K}$ content was established from samples diluted to $100 \mathrm{~cm}^{3}$. The nitrogen content was measured with a Parnass-Wagner water steam distiller apparatus. The phosphorus content was measured with the aid of the vanadate-molybdate procedure. A spectrophotometer (Spekol 221) was used for measuring the extinction of the yellow-coloured solution. The potassium

Tab. 2. Key pedological data of experiment

\begin{tabular}{ccccccccc}
\hline Genetic soil level & $\begin{array}{c}\mathrm{pH} \\
\left(\mathrm{H}_{2} \mathrm{O}\right)\end{array}$ & $\begin{array}{c}\text { Liquid } \\
\text { limit }\end{array}$ & $\begin{array}{c}\text { Humus } \\
(\%)\end{array}$ & $\mathrm{CaCO}_{3}(\%)$ & $\begin{array}{c}\sum \text { salt } \\
(\%)\end{array}$ & $\begin{array}{c}\text { Total N } \\
(\mathrm{mg} / \mathrm{kg})\end{array}$ & $\begin{array}{c}\mathrm{AL}_{2} \mathrm{P}_{2} \mathrm{O}_{5} \\
(\mathrm{mg} / \mathrm{kg})\end{array}$ & $\begin{array}{c}\mathrm{AL}^{\mathrm{K}} \mathrm{K}_{2} \mathrm{O} \\
(\mathrm{mg} / \mathrm{kg})\end{array}$ \\
\hline $\mathrm{A}(0-40 \mathrm{~cm})$ & 6.76 & 30 & 1.32 & 0.00 & 0.044 & 16.8 & 371.1 & 184.0 \\
$\mathrm{~B}(40-60 \mathrm{~cm})$ & 7.08 & 40 & 1.04 & 0.00 & 0.052 & 11.9 & 33.0 & 112.0 \\
$\mathrm{BC}(60-70 \mathrm{~cm})$ & 7.66 & 61 & 0.88 & 0.00 & 0.060 & 2.0 & 123.0 & 127.1 \\
$\mathrm{C}(70-100 \mathrm{~cm})$ & 8.10 & 60 & 0.54 & 5.57 & 0.075 & 16.8 & 107.5 & 110.8 \\
\hline
\end{tabular}


Tab. 3. The seeds requirement of green manure plants (Antal, 2000)

\begin{tabular}{ccc}
\hline Plants & $\begin{array}{c}\text { Germ number } \\
(\mathrm{seed} / \mathrm{ha})\end{array}$ & $\begin{array}{c}\text { Seed requirement } \\
(\mathrm{kg} / \mathrm{ha})\end{array}$ \\
\hline Phacelia tanacecifolia(I.) & 5000000 & 10 \\
Sinapis alba (II.) & 2000000 & 15 \\
Raphanus sativus (III.) & 2500000 & 25 \\
\hline
\end{tabular}

content was measured from the solutions and dilution series referred to in the description of the establishment of the phosphorus content, with flame photometer (Jenway PFP 7).

The statistical evaluation was carried out with the EXCEL program, through one- and two-factor variance analysis.

\section{Results and discussion}

The amount of precipitation had a significant impact on the biomass production of the green manure plants (Tab.4). The impact of the growing season's conditions was particularly heavy on the parcels without fertiliser application. P. tanacecifolia produced a green mass of only $4.8 \mathrm{t} /$ ha in 2009 without fertiliser, in contrast to the $18.4 \mathrm{t} / \mathrm{ha}$ in the rainy year of 2007. P. tanacecifolia could not produce the minimum expected $10 \mathrm{t} / \mathrm{ha}$ green mass (Buckles et al., 1998) in 2008 and 2009 without $\mathrm{N}$ supplementation. As a result of $\mathrm{N}$ top-dressing the green mass increased by 1.91 3.95 times, with a 3.11 times increase as an average of the three years concerned. The drought in 2009 had a severely adverse impact on $P$. tanacecifolia but the $\mathrm{N}$ supplement resulted in a substantial improvement in the plant's stress tolerance and in its water utilisation, as a result of which it produced a green mass of $16.7 \mathrm{t} / \mathrm{ha}$ (Tab. 4).

In the case of $S$. alba the green mass without $\mathrm{N}$ was below $10 \mathrm{t} / \mathrm{ha}$ (that is, $7.3 \mathrm{t} / \mathrm{ha}$ ) in 2008 , while the $50 \mathrm{~kg} / \mathrm{ha}$ $\mathrm{N}$ content increased the green mass of this plant to $31.7 \mathrm{t} /$ ha. The three year average of the green mass increment was 3.09 times, with a $35.4 \mathrm{t} / \mathrm{ha}$ average green mass produce.

In the case of $R$. sativus it was found more balanced yield levels, the different growing seasons had smaller impacts on this crop. Without fertiliser and with fertiliser the green mass varied between 9.8 and $13.9 \mathrm{t} / \mathrm{ha}$ and between 26.6 and $34.4 \mathrm{t} / \mathrm{ha}$, respectively. The small $\mathrm{N}$ dose increased the green mass production by 2.19-13.9 times.

The absolute dry mass per hectare figures reflected the trends described with regard to the green mass, however, as a result of the application of $\mathrm{N}$ fertiliser the growth in the dry mass yield fell short of the increase in the green mass by $94 \%$ in the case of $P$. tanacecifolia, by $43 \%$ in the case of $S$. alba and by $118 \%$ in the case of $R$. sativus. This is explained by the fact that the water content of the green manure plants also increased as a result of the $\mathrm{N}$ supplement.

The nitrogen content per-hectare was measured in 2008 and 2009 (Tab. 5), in P. tanacecifolia the $\mathrm{N}$-content per hectare increased by 3.32 times, from $30.9 \mathrm{~kg} / \mathrm{ha}$ to $102.1 \mathrm{~kg} / \mathrm{ha}$ as an average of the two years. The $50 \mathrm{~kg} / \mathrm{ha}$ $\mathrm{N}$ fertiliser enabled the uptake of an additional $71.2 \mathrm{~kg} /$ ha nitrogen. With the supplementary nitrogen supply the per-hectare nitrogen content of $P$. tanacecifolia matched the amount found in the experiment of Thorup-Kristensen (2001).

In the case of $S$. alba the nitrogen uptake per hectare increased by 3.73 times as an average during the two years of experiments. The $50 \mathrm{~kg} \mathrm{~N}$ fertiliser enabled the uptake of an additional $151.6 \mathrm{~kg}$ of nitrogen per hectare. Nitrogen transport is very fast in S. alba (Corbesier et al., 2001), therefore it can very quickly take up the soil's available nitrogen content. Like the amount of biomass produced by this species however (Brant et al., 2009), the amount of the nitrogen uptake is also heavily affected by the growing season effect.

In the case of $R$. sativus the amount of active ingredient taken up by the plants increased by an average of 3.54

Tab. 4. The green and dry mass of green manuring plants (t/ha) (Gödöllö, 2007-2009)

\begin{tabular}{|c|c|c|c|c|c|c|c|c|c|c|c|}
\hline \multirow{2}{*}{\multicolumn{2}{|c|}{ Treatments }} & \multicolumn{5}{|c|}{ Green mass } & \multicolumn{5}{|c|}{ Dry mass } \\
\hline & & 2007 & 2008 & 2009 & Average & $\mathrm{LSD}_{5 \%}$ & 2007 & 2008 & 2009 & Average & $\mathrm{LSD}_{5 \%}$ \\
\hline \multirow{4}{*}{ I. } & $\mathrm{NF}$ & 18.4 & 9.7 & 4.8 & 11.0 & \multirow{4}{*}{2.2} & 3.2 & 1.3 & 0.9 & 1.8 & \multirow{4}{*}{0.2} \\
\hline & WF & 35.2 & 38.5 & 16.7 & 30.2 & & 4.5 & 3.2 & 2.3 & 3.3 & \\
\hline & $\mathrm{CNC}$ & 191 & 395 & 345 & 311 & & 141 & 242 & 267 & 217 & \\
\hline & $\mathrm{LSD}_{5 \%}$ & \multicolumn{4}{|c|}{2.9} & & \multicolumn{4}{|c|}{0.3} & \\
\hline \multirow{4}{*}{ II. } & $\mathrm{NF}$ & 12.9 & 7.3 & 16.6 & 12.3 & \multirow{4}{*}{1.2} & 3.0 & 1.1 & 2.1 & 2.1 & \multirow{4}{*}{0.3} \\
\hline & WF & 26.3 & 31.7 & 48.2 & 35.4 & & 4.9 & 3.6 & 6.7 & 5.1 & \\
\hline & $\mathrm{CNC}$ & 204 & 433 & 291 & 309 & & 165 & 310 & 323 & 266 & \\
\hline & $\mathrm{LSD}_{506}$ & \multicolumn{4}{|c|}{3.8} & & \multicolumn{4}{|c|}{0.6} & \\
\hline \multirow{4}{*}{ III. } & $\mathrm{NF}$ & 13.9 & 9.8 & 10.3 & 11.3 & \multirow{4}{*}{1.9} & 2.8 & 1.3 & 1.6 & 1.9 & \multirow{4}{*}{0.3} \\
\hline & WF & 30.4 & 27.6 & 34.4 & 30.8 & & 4.0 & 2.8 & 4.8 & 3.9 & \\
\hline & $\mathrm{CNC}$ & 219 & 282 & 333 & 278 & & 141 & 212 & 293 & 215 & \\
\hline & $\mathrm{LSD}_{5 \%}$ & \multicolumn{4}{|c|}{3.4} & & \multicolumn{4}{|c|}{0.4} & \\
\hline
\end{tabular}


50

Tab. 5. Effects of different nutrient levels on the uptake of $\mathrm{N}_{2} \mathrm{P}_{2} \mathrm{O}_{5}$ and $\mathrm{K}_{2} \mathrm{O}$ amount of green manure plants (kg/ha) (Gödöllö, 2008-2009)

\begin{tabular}{|c|c|c|c|c|c|c|c|c|c|c|c|c|c|}
\hline \multicolumn{2}{|c|}{ Treatments } & \multicolumn{4}{|c|}{$\mathrm{N}$} & \multicolumn{4}{|c|}{$\mathrm{P}_{2} \mathrm{O}_{5}$} & \multicolumn{4}{|c|}{$\mathrm{K}_{2} \mathrm{O}$} \\
\hline & & 2008 & 2009 & AVG & $\mathrm{LSD}_{50}$ & 2008 & 2009 & AVG & $\mathrm{LSD}_{5 \%}$ & 2008 & 2009 & AVG & $\mathrm{LSD}_{5 \%}$ \\
\hline \multirow[t]{4}{*}{ I. } & NF & 30.1 & 31.7 & 30.9 & \multirow[t]{4}{*}{16.4} & 13.9 & 8.7 & 11.3 & \multirow{4}{*}{5.5} & 75.2 & 34.0 & 54.6 & \multirow[t]{4}{*}{23.6} \\
\hline & WF & 118.2 & 86.1 & 102.1 & & 43.5 & 23.2 & 33.4 & & 179.5 & 97.8 & 138.7 & \\
\hline & $\mathrm{CNC}$ & 393 & 271 & 332 & & 313 & 265 & 289 & & 239 & 287 & 263 & \\
\hline & $\mathrm{LSD}_{5 \%}$ & & 13.0 & & & & 6.2 & & & & 23.9 & & \\
\hline \multirow[t]{4}{*}{ II. } & NF & 33.6 & 85.2 & 59.4 & \multirow[t]{4}{*}{43.7} & 12.7 & 22.7 & 17.7 & \multirow[t]{4}{*}{11.8} & 52.3 & 91.6 & 72.0 & \multirow[t]{4}{*}{37.5} \\
\hline & WF & 138.8 & 283.2 & 211.0 & & 32.3 & 61.8 & 47.0 & & 183.2 & 218.4 & 200.8 & \\
\hline & $\mathrm{CNC}$ & 413 & 333 & 373 & & 254 & 272 & 263 & & 350 & 238 & 294 & \\
\hline & $\mathrm{LSD}_{5 \%}$ & & 25.4 & & & & 10.6 & & & & 24.6 & & \\
\hline \multirow[t]{4}{*}{ III. } & NF & 31.1 & 57.4 & 44.3 & \multirow[t]{4}{*}{26.4} & 18.3 & 17.3 & 17.8 & \multirow{4}{*}{9.6} & 58.0 & 62.1 & 60.0 & \multirow[t]{4}{*}{40.8} \\
\hline & WF & 127.0 & 172.0 & 149.5 & & 34.1 & 58.4 & 46.2 & & 126.8 & 175.6 & 151.2 & \\
\hline & $\mathrm{CNC}$ & 409 & 299 & 354 & & 186 & 338 & 262 & & 219 & 283 & 251 & \\
\hline & $\mathrm{LSD}_{5 \%}$ & & 17.5 & & & & 9.1 & & & & 13.5 & & \\
\hline
\end{tabular}

Tab. 6. Specific biomass increasing effect of $1 \mathrm{~kg}$ additional $\mathrm{N}$ ( $\mathrm{kg} / \mathrm{ha})$

\begin{tabular}{ccccccc}
\hline Plants & Biomass & 2007 & 2008 & 2009 & Average & LSD $_{5 \%}$ \\
\hline I. & Green mass & 336.1 & 575.8 & 238.0 & 455.9 & 167.3 \\
& Dry mass & 26.2 & 37.4 & 28.0 & 31.8 & NS \\
\hline \multirow{2}{*}{ II. } & Green mass & 268.5 & 487.3 & 632.0 & 377.9 & 90.1 \\
& Dry mass & 38.9 & 48.1 & 92.0 & 43.5 & 20.6 \\
\hline \multirow{2}{*}{ III. } & Green mass & 329.8 & 356.1 & 482.0 & 342.9 & NS \\
& Dry mass & 23.1 & 30.2 & 64.0 & 26.6 & 20.7 \\
\hline
\end{tabular}

Tab. 7. Specific NPK content increasing effect of $1 \mathrm{~kg}$ additional $\mathrm{N}(\mathrm{kg} / \mathrm{ha})$

\begin{tabular}{cccccc}
\hline Plants & $\mathrm{NPK}$ & 2008 & 2009 & Average & LSD $_{5 \%}$ \\
\hline I. & $\mathrm{N}$ & 1.8 & 1.1 & 1.4 & $\mathrm{NS}$ \\
& $\mathrm{P}_{2} \mathrm{O}_{5}$ & 0.6 & 0.3 & 0.4 & 0,2 \\
& $\mathrm{~K}_{2} \mathrm{O}$ & 2.1 & 1.3 & 1.7 & $\mathrm{NS}$ \\
\hline II. & $\mathrm{N}$ & 2.1 & 4.0 & 3.0 & $\mathrm{NS}$ \\
& $\mathrm{P}_{2} \mathrm{O}_{5}$ & 0.4 & 0.8 & 0.6 & $\mathrm{NS}$ \\
& $\mathrm{K}_{2} \mathrm{O}$ & 2.6 & 2.5 & 2.6 & $\mathrm{NS}$ \\
\hline III. & $\mathrm{N}$ & 1.9 & 2.3 & 2.1 & $\mathrm{NS}$ \\
& $\mathrm{P}_{2} \mathrm{O}_{5}$ & 0.3 & 0.8 & 0.6 & 0.4 \\
& $\mathrm{~K}_{2} \mathrm{O}$ & 1.4 & 2.3 & 1.8 & $\mathrm{NS}$ \\
\hline
\end{tabular}

times in the two years concerned, i.e. the $50 \mathrm{~kg} / \mathrm{ha}$ applied nitrogen resulted in the uptake of an additional $105.2 \mathrm{~kg}$ nitrogen per hectare. With the nitrogen supplement it was also found results similar to those measured in the ThorupKristensen (2001) experiment in regard to the per-hectare nitrogen content of $R$. sativus.

As an average of the two years, the $\mathrm{P}_{2} \mathrm{O}_{5}$ content increased in P. tanacecifolia, $S$. alba and $R$. sativus by 2.89 , 2.63 and 2.62 times, respectively. The application of nitrogen fertiliser resulted in the uptake of $22.1 \mathrm{~kg}, 29.3 \mathrm{~kg}$ and $28.4 \mathrm{~kg}$ of additional amounts of $\mathrm{P}_{2} \mathrm{O}_{5}$ in $P$. tanacecifolia, $S$. alba and $R$. sativus respectively, as an average over the two years of the experiments. The increase in the per-hectare $\mathrm{P}_{2} \mathrm{O}_{5}$ uptake is explained by Liebig's minimum law.
As an average of the two years, the $\mathrm{K}_{2} \mathrm{O}$ content increased in $P$. tanacecifolia, $S$. alba and $R$. sativus by 2.63 , 2.94 and 2.51 times, respectively. The application of nitrogen fertiliser resulted in the uptake of $84.1 \mathrm{~kg}, 128.8 \mathrm{~kg}$ and $91.2 \mathrm{~kg}$ of additional amounts of $\mathrm{K}_{2} \mathrm{O}$ in $P$. tanacecifolia, $S$. alba and $R$. sativus respectively, as an average over the two years of the experiments.

It was not always possible to identify a significant difference between the biomass increase caused by a unit ( 1 $\mathrm{kg}$ ) of nitrogen active ingredient and the growing season effect (Tab. 6). However, the biomass increasing impact of a unit of nitrogen was found to be significant. As an average of the three years one kilogram of nitrogen active ingredient resulted in a $455.9 \mathrm{~kg}$ increases in the green mass and by $31.8 \mathrm{~kg}$ increases in the dry mass content of $P$. tanacecifolia. In the case of $S$. alba and $R$. sativus the green mass increased by $377.9 \mathrm{~kg}$ and $342.9 \mathrm{~kg}$ while the dry mass grew by $43.5 \mathrm{~kg}$ and by $26.6 \mathrm{~kg}$, respectively.

The growing season had no effect on the increase in the NPK content taken up per hectare caused by one unit of active ingredient, apart from the $\mathrm{P}_{2} \mathrm{O}_{5}$ content of $P$. tanacecifolia and $R$. sativus, (Tab. 7). The amount of the nutrient uptake increased regardless of the amount of precipitation. As an average over the 2008-2009 period one kilogram of nitrogen resulted in the uptake of $1.4 \mathrm{~kg}, 3.0$ $\mathrm{kg}$ and $2.1 \mathrm{~kg}$ of additional nitrogen in $P$. tanacecifolia, $S$. alba and $R$. sativus. Accordingly, the intermediate catch crops did play a major role in the nitrogen transports (Allison et al., 1998a, 1998b; Thorup-Kristensen et al., 2003). This is an all the more important finding in view of the poor nitrogen supply of the site of the experiment.

The additional nitrogen application resulted in an increase in the availability of $\mathrm{P}_{2} \mathrm{O}_{5}$ as well, each kg of additional nitrogen resulted in the uptake of an additional 0.4 $\mathrm{kg}$ of $\mathrm{P}_{2} \mathrm{O}_{5}$ in $P$. tanacecifolia and $0.6 \mathrm{~kg}$ in $S$. alba and in $R$. sativus. The additional nitrogen contributed to increased $\mathrm{K}_{2} \mathrm{O}$ uptake: by $1.7 \mathrm{~kg}$ in $P$. tanacecifolia, $2.6 \mathrm{~kg}$ in $S$. alba and by $1.8 \mathrm{~kg}$ in $R$. sativus. 


\section{Conclusions}

Each of the plant species studied in the experiment was suitable for use as green manure under the given unfavourable site conditions, fulfilling their soil protecting and organic matter preserving functions. In terms of the biomass and nutrient content parameters, particularly in terms of the $\mathrm{N}$ uptake per-hectare however, the cruciferous $S$. alba and $R$. sativus were found to be more favourable than $P$. tanacecifolia. The application of small doses $(50 \mathrm{~kg} / \mathrm{ha})$ of nitrogen resulted, in each of the years of the experiments, in substantial increases in the total biomass and the nutrient content parameters, while without the application of nitrogen the next crop suffered from pentosan effect. The delivery of nitrogen fertiliser multiplied the crop's nitrogen content in each of the three plants. The use of nitrogen fertiliser boosted the uptake of phosphorus and potassium as well.

In response to the delivery of the small dose of $50 \mathrm{~kg} /$ ha nitrogen each of the three plant species involved in the experiments produced a stable green mass yield and substantial amounts of NPK stored in the green mass but without the nitrogen supplement it was not always possible to produce adequate amounts of biomass in the low quality site. The results showed that in the production of green manure crops nitrogen should preferably be applied in the given site in general, but if the straw after harvesting cereal precrops is not removed from the field, nitrogen should be applied by all means.

\section{References}

Allison MF, Armstrong MJ, Jaggard KW, Todd AD (1998a). Integration of nitrate cover crops into sugarbeet (Beta vulgaris) rotations. I. Management and effectiveness of nitrate cover crops. J Agric Sci 130:53-60.

Allison MF, Armstrong MJ, Jaggard KW, Todd AD (1998b). Integration of nitrate cover crops into sugarbeet (Beta vulgaris) rotations. II. Effect of cover crops on growth, yield and $\mathrm{N}$ requirement of sugarbeet. J Agric Sci 130:61-67.

Andraski TW, Bundy LG (2005). Cover crop effects on corn yield response to nitrogen on an irrigated sandy soil. Agro J 97:1239-1244.

Antal J (2000). Növénytermesztők zsebkönyve. (Pocketbook of Crop Producers) Mezőgazda Kiadó. Budapest.

Axelsen JA, Kristensen KT (2000). Collembola and mites in plots fertilised with different types of green manure. Pedobiologia 44:556-566.

Birkás M (2010). Long-term experiments aimed at improving tillage practices. Acta Agron Hungarica 58(1):75-81.

Bolton H, Elliott LF, Papendick RI, Bezdicek DF (1985). Soil microbial biomass and selected soil enzyme activities: effect of fertilization and cropping practices. Soil Biol Biochem 17(3):297-302.
Brant V, Neckár K, Pivec J, Duchoslav M, Holec J, Fuksa P, Venclová (2009). Competition of some summer catch crops and volunteer cereal svin the areas with limited precipitation. Plant Soil Environ 55(1):17-24.

Breland TA (1995). Ryegrass and white clover undersown in small grains at three $\mathrm{N}$ levels and four tillage treatments: effects on soil mineral nitrogen. Soil Use Manage 11(4):163167.

Buckles D, Triomphe B, Sain G (1998). Cover crops in hillside agriculture: farmer innovation with mucuna. International Development Research Centre Ottawa. Canada.

Burket JZ, Hemphill DD, Dick RP (1997). Winter cover crops and nitrogen management in sweet corn and broccoli rotations. Hort Sci 32:664-668.

Chikaoka I, Onbayash NP, Suina S (1982). The effect of green manure, marigold, groundnut, sorghum and watermelon on the population dynamics of Pratylenchus penetrans and Meloidogyne incognita. Jap J Nematol 11:19-23.

Corbesier L, Havelange A, Lejeune P, Bernier G, Perilleux C (2001). N content of phloem and xylem exudates during the transition to flowering in Sinapis alba and Arabidopsis thaliana. Plant Cell Environ 24(3):367-375.

Dickson DW, Hewlett TE (1989). Effect of bahiagrass and nematicides on Meloidogyne arenaria on peanut. J Nematol 21:671-676.

Djordjevic N, Dinic B, Grubic G, Vuckovic S, Simic A (2005). The quality and chemical composition of Phacelia tanacetifolia Benth. and lucerne silages. Integrating efficient grassland farming and biodiversity. Proc of the $13^{\text {th }}$ International Occasional Symposium of the European Grassland Federation, Tartu, Estonia, 29-31 August 2005.

Duddington CL, Duthoit CMG (1960). Green manuring and cereal root eelworm. Plant Pathol 9(1):7-9.

Duddington CL, Everard COR, Duttoit CMG (1961). Effect of green manuring and a predacious fungus on cereal root eelworm in oats. Plant Pathol 10:108-109.

Hall JK, Hartwig NK (1989). Triazine herbicide fate in a notillage corn (Zea mays L.)-crownvetch (Coronilla varia L.) living mulch system. Agric Ecosyst Environ 30:281-293.

Henderson CWL (1989). Lupins as a biological plough: evidence for and effects on wheat growth and yield. Austr J Experiment Agric 29:99-102.

Inderjit R (2004). Weed Biology and Management. Kluwer Akademic Publishers. The Netherlends.

Johnson LF, Chambers AY, Reed HE (1967). Reduction of rootknot of tomatodes with crop residues amendment in field experiments. Plant Dis Rep 51:219-222.

Kahnt G (1983). Gründüngung. DLG-Verlags-GmbH. Frankfurt an Main.

Larson JA, Roberts RK, Tyler DD, Duck BN, Slinsky SP (1998). Stochastic dominance analysis of winter cover crop and nitrogen fertilizer systems for no-tillage corn. J Soil Water Conserv 53(3):285-288. 
52

Lewis JA, Papavizas GC (1971). Effect of sulphur-containing volatile compounds and vapors from cabbage decomposition on Apnanomyces euteiches. Phytopathol 61:208-214.

Mojtahedi H, Santo GS, Hang AN, Wilson JH (1991). Suppression of root-knot nematode populations with selected rapeseed cultivars in green manure. J Nematol 23:170-174.

Mojtahedi H, Santo GS, Wilson JH, Hang AN (1993). Managing Meloidogyne chitwoodi on potato with rapeseed as green manure. Plant Dis 77:42-46.

Muller JC, Denys D, Morlet G, Mariotta A (1989). Influence of catch crops on mineral nitrate leaching and its subsequent plant use. In: Germon JC, Dupain S (Eds.). Management systems to reduce impact of nitrates. New York. Elsevier Applied Science, 85-98 p.

Rasmussen KJ, Andersen A (1994). 13 years experiments with soil tillage and incorporation of straw and catch crop on a marsh soil. Statens Planteavlsforsoeg Lyngby (Denmark) $13: 22$.
Smith MS, Frye WW, Varco JJ (1987). Legume winter crops. Adv Soil Sci 7:95-139.

Stivers-Young L (1998). Growth, nitrogen accumulation, and weed suppression by fall cover crops following early harvest of vegetables. Hort Sci 33:60-63.

Thorup-Kristensen K (2001). Are differences in root growth of nitrogen catch crops important for their ability to reduce soil nitrate-N content, and how can this be measured? Plant and Soil 230:185-195.

Thorup-Kristensen K, Magid J, Jensen LS (2003). Catch crops and green manures as biological tools in nitrogen management in teperate zones. Adv Agron 79:227-302.

Unger PE, Vigil MF (1998). Cover crops effects on soil water relationships. Jo Soil Water Conserv 53(3):200-207. 